\title{
Accounting
}

\section{The impact of real effective exchange rate volatility on trade balance in Vietnam}

\author{
Nguyen Thi My Linh ${ }^{a}$ and Nguyen Thi Kim Lien ${ }^{\text {** }}$
}



\section{Introduction}

According to Alfred Marshall and Abba Lerner (the Marshall-Lerner condition), currency devaluation has a positive impact on the trade balance (Boyd et al., 2001). Currency devaluation leads to a decline in the price of nominal exports in foreign currencies; therefore, the demand for goods of foreigners will increase, facilitating exports. Simultaneously, currency devaluation makes the price of nominal imports in domestic currency relatively higher, reducing the demand for imports of local people. However, the net effect of devaluation on the balance of payments depends on price elasticities. For the Marshall-Lerner condition to work, the absolute value of the sum of the two price elasticities of exports and imports must be greater than one. If the exports are elastic concerning price, the increase in their quantity demanded will be greater than the decrease in price; therefore, the export turnover will increase. Similarly, if the imports are price elastic, the import expenditure will decrease. Both of these factors contribute to the improvement of the trade balance. Most empirical studies show that goods are not often priced elastic in the short run because consumption habits cannot change easily. For this reason, in the short run, the Marshall-Lerner condition is not met, which leads to the fact that currency devaluation only worsens the short-run trade balance. In the long run, when consumers adjust their consumption habits to new prices, the trade balance is improved. The fact from the empirical studies shows that the impact of exchange rate volatility on the trade balance in countries is not the same. Specifically, the studies undertaken by Koray and Lastrapes (1989), Gil-Alana et al. (2008), Baharumshah (2001), Cao-Alvira (2014), Dogru,

* Corresponding author

E-mail address: nguyenthikimlien@iuh.edu.vn (N. T. Kim Lien) 
Isik and Sirakaya-Turk (2019) show that the exchange rate volatility has an impact on the trade balance in the studied countries. In Vietnam, Do Thi Man (2017) concludes that the real effective exchange rate has an impact on Vietnam's trade balance in the long run (with the lag of 5 periods). This conclusion is based on a study with a database of bilateral nominal rates and CPI of 20 major trading partners of Vietnam. In agreement with Do Thi Man (2017), Nguyen Thi Van Nga (2018) also believes that there exists a long-run relationship between exchange rate volatility and Vietnam's trade balance in the research period from 2000 to 2006, based on the real effective exchange rate database of Vietnam and 14 major trading partners. However, some other authors did not find statistical significance when examining the impact of exchange rate volatility on the trade balance, such as Singh (2014) in India, Yol and Baharumshah (2007) in Ghana, Morocco and Senegal, Celik and Kaya (2010) in Turkey, etc. As a result, these researchers have not yet reached a consensus on the impact of exchange rate volatility on the trade balance.

In Vietnam, the country has experienced a long time with a trade deficit and frequent trade balance deficits. To stabilize the macro-economic situation, the exchange rate policy that Vietnam is pursuing is to float the exchange rate under the control of the State. Accordingly, the State intervenes in the exchange rate by adjusting the increase or decrease in the amplitude of the exchange rate in line with the orientation of the State, represented by the State Bank of Vietnam. With such an exchange rate regime, does the exchange rate volatility have a certain effect on the trade balance? To find the answer to the impact of exchange rate volatility in the context of applying the real effective exchange rate of the Vietnamese currency with 143 major trading partners of Vietnam on the trade balance in the period of 2002 - 2019, the authors conducted this study. The research results help policymakers to have a more comprehensive view and have a reasonable exchange rate management policy to improve the trade balance in Vietnam (Ngo et al., 2020).

\section{Literature Review}

\subsection{The impact of exchange rate volatility on the trade balance}

Koray and Lastrapes (1989) used VAR models to investigate the impact of real exchange rate volatility on US bilateral imports from the United Kingdom, France, Germany, Japan and Canada. The result shows that the shocks of one-period exchange rate volatility tend to have inconsiderable negative impacts on imports in the first 12 months. In other cases, a constant shock of exchange rate volatility leads to a decrease in imports. This negative effect is consistent with the common assumption that exchange rate volatility has a negative impact on trade. Baharumshah (2001) identified the main economic factors that influence the trade balance of Malaysia and Thailand with the two main partners, the US and Japan. The study used VAR model with quarterly frequency data from Quarter 1 of 1980 to Quarter 4 of 1996. The study found that the real effective exchange rate is an important variable affecting the trade balance and devaluation improves the trade balance in the long run. The devaluation of the ASEAN currencies improves the trade balance between the US and Japan. Cao-Alvira (2014) assessed the short-run and long-run effects of real exchange rate volatility on Colombian bilateral trade balance of commodities and non-commodities with its main trading partners, Germany, Belgium, China, the US, and Switzerland. The research results show that in the short run, Colombian non-commodity trade responds higher to exchange rate volatility than commodity trade. Do Thi Man (2017) examined the real effective exchange rate and the trade balance in Vietnam in the period of 2000 - 2016 using the VAR model. The study used the variable of real effective exchange rate calculated from the data on the bilateral nominal exchange rates and CPI of 20 major trading partners of Vietnam. The results confirm that the real effective exchange rate has an impact on Vietnam's trade balance in the long run (with the lag of 5 periods). Nguyen Thi Van Nga (2018) used the time series data from 2000 to 2006 to assess the impact of exchange rate volatility on Vietnam's trade balance. The study utilized the ARCH model to calculate the real exchange rate volatility based on the data on real effective exchange rate of Vietnam and 14 major trading partners. The research results show that there exists a long-run relationship between exchange rate volatility and Vietnam's trade balance. Dogru et al. (2019) measured the impact of exchange rate volatility on the US bilateral tourism trade balance with Canada, Mexico and the United Kingdom through the ARDL technique. The research results show that the depreciation of the US dollar improves the US trade balance with all three trading partners.

\subsection{There is no comprehensive statistical evidence on the impact of exchange rate volatility on the trade balance}

Hooper and Kohlhagen (1978) considered the effect of bilateral nominal exchange rate volatility on the US and Germany bilateral trade balance in the period of 1969 - 1975. The research results show that exchange rate volatility has a significant impact on commodity prices but it does not significantly affect the total volume of the trade balance. Specifically, the increase in the exchange rate volatility increases the variance of profits and moves the demand curve down, leading to a decrease in the quantity and prices of commodities. The exchange rate volatility only affects the trade balance without hedging exchange rate risks. Thus, if international partners are concerned about exchange rate risks and conducting hedging risks, there is not enough basis to conclude that exchange rate volatility reduces the trade balance. Singh (2004) analyzed the impact of exchange rate volatility on the trade balance in India based on the quarterly data from Quarter 2 of 1975 to Quarter 3 of 1996 . The study found no statistically significant evidence of the effects of exchange rate volatility on the trade balance in India. Yol and Baharumshah (2007) examined the impact of the exchange rate on the bilateral trade balance of 10 African countries with the US, using the FMOLS regression technique with the annual data throughout $1977-2002$. The research results show that there was no statistically significant evidence of the impact of exchange rate volatility on the trade balance in Ghana, Morocco and Senegal. 
Ikelik and Kaya (2010) analyzed the factors affecting Turkey's bilateral trade concerning a panel of seven partner countries. The study shows that the impact of the exchange rate on Turkey's trade balance with different partners is inconsistent and countryspecific.

\section{Research methodology}

During the past time, the studies on the relationship between the exchange rate and the trade balance in the world are very diverse and plentiful in data and research models. In general, the studies used ARDL, VAR, VECM techniques and OLS or FMOLS tests to measure the impact of the exchange rate on a country's parallel trade balance with selected partners. For the variables used in the research model, in the period before 2000, several studies were using the variable of nominal exchange rate, such as Hooper and Kohlhagen (1978. Later, many studies used the variable of real exchange rate, mainly bilateral real exchange rate (for example, Dogru, Isik and Sirakaya-Turk, 2019; Yol and Baharumshah, 2007; Çelik and Kaya, 2010) and real effective exchange rate (Baharumshah, 2001; Do Thi Man, 2017) in the research model. In particular, Do Thi Man's (2017) study on the relationship between real exchange rate and Vietnam's trade balance used the variable of real effective exchange rate (REER) which was calculated from the data on the bilateral nominal exchange rates and CPI of 20 major trading partners of Vietnam. Within the scope of this study, the authors applied the VAR model to estimate the impact of exchange rate volatility on Vietnam's trade balance with the new point of using the variable of real effective exchange rate (REER) of the Vietnamese currency with 143 major trading partners of Vietnam. According to Crowley and Lee (2003), the authors calculate the index of real effective exchange rate volatility (vol_reer) based on the quarterly data on the real effective exchange rate, by using the following GARCH $(1,1)$ model:

$$
\begin{aligned}
& \text { vol_reer }_{\mathrm{t}}=\beta_{1}+\mathrm{u}_{\mathrm{t}} \\
& \mathrm{u}_{\mathrm{t}} \approx N\left(0, h_{t}\right) \\
& h_{t}=\gamma_{0}+\sum_{j=1}^{p} \gamma_{j} u_{t-j}^{2}+\sum_{i=1}^{q} \delta_{i} h_{t-i}
\end{aligned}
$$

where vol_reer,$u_{t}$ and $h_{t}$ real exchange rate volatility, random error and variance of real exchange rate, respectively.

\section{Research model}

The purpose of this study is to measure the impact of exchange rate volatility on the trade balance in Vietnam in the period of 2002 - 2019, with the quarterly frequency data. Based on the VAR model on the relationship between exchange rate and the trade balance of previous studies such as Baharumshah (2001), Do Thi Man (2017), the research model is as follows:

$$
t b_{t}=\alpha_{0}+\sum_{j=1}^{n} \alpha_{1 j} t b_{t-j}+\sum_{j=1}^{n} \alpha_{2 j} \text { vol_reer } t-j+\varepsilon_{t}
$$

Where vol_reer and tb are real effective exchange rate volatility and Vietnam's trade balance, respectively.

Table 1

Variables used in the research model

\begin{tabular}{lcccc}
\hline \multicolumn{1}{c}{ Variable name } & $\begin{array}{c}\text { Variable } \\
\text { code }\end{array}$ & Definition & Source of data & Previous studies \\
\hline $\begin{array}{l}\text { real effective exchange rate } \\
\text { volatility }\end{array}$ & vol_reer & $\begin{array}{l}\text { Vietnam's } \\
\text { effective exchange rate } \\
\text { volatility }\end{array}$ & Bruegel & $\begin{array}{l}\text { Koray and Lastrapes (1989); Singh (2004); Cao-Alvira } \\
(2014) ; \text { Nguyen Thi Van Nga (2018); Musila (2002) }\end{array}$ \\
Trade balance & tb & $\begin{array}{c}\text { Vietnam's trade } \\
\text { balance (export - } \\
\text { import) }\end{array}$ & $\begin{array}{c}\text { Statistics Office } \\
\text { of Vietnam }\end{array}$ & $\begin{array}{l}\text { Hooper and Kohlhagen (1978); Baharumshah (2001); Yol } \\
\text { Man (2017); Dogru, Isik and Sirakaya-Turk (2019) }\end{array}$ \\
\hline
\end{tabular}

Source: The authors' synthesis

\section{Research results and discussion}

\subsection{Calculation results of real exchange rate volatility using the GARCH $(1,1)$ model}

In general, the real effective exchange rate in Vietnam during the period of 2002 - 2019 was steady in most phases, except for the phase of the global financial crisis in 2008 and 2009 with the largest volatility in Quarter 1 of $2019(0.18 \%)$. After the crisis, the exchange rate volatility was relatively stable and slightly increased in Quarter 2 of $2015(0.10 \%)$. 




Fig. 1. Volatility of the real effective exchange rate in Vietnam in the period of $2002-2019$

Source: The authors' analysis results

5.2 Tests

\section{Stationarity test of variables}

The study used Dickey-Fuller test (Dickey and Fuller, 1979) to test the stationarity of data series. With the hypothesis $\mathrm{H}_{0}$ : the data series is not stationary.

Table 2

Dickey-Fuller test for unit root

\begin{tabular}{cc}
\hline Variable & Original data series \\
\hline vol_reer & $0.0014^{* * *}$ \\
tb & $0.0181^{* *}$ \\
\hline
\end{tabular}

Note: *,** and *** indicate significance at the 10\%, 5\% and 1\% levels, respectively. Source: The authors' analysis results

The stationarity test results showed that both data series stopped at the original data series.

\section{Determine the optimal lag}

\section{Table 3}

Determine the optimal lag of variables

\begin{tabular}{ccccccccc}
\hline Lag & LL & LR & df & P & FPE & AIC & HQIC & SBIC \\
\hline 0 & -148.35 & & & & 0.326377 & 4.55605 & 4.58227 & 4.6224 \\
1 & -103.87 & 88.96 & 4 & 0.000 & 0.095728 & 3.32939 & $3.40804^{*}$ & $3.52845^{*}$ \\
2 & -102.788 & 2.1626 & 4 & 0.706 & 0.104628 & 3.41783 & 3.54893 & 3.7496 \\
3 & -94.0202 & 17.537 & 4 & 0.002 & 0.090644 & 3.27334 & 3.45687 & 3.73781 \\
4 & -88.3901 & $11.26^{*}$ & 4 & 0.024 & $0.086432^{*}$ & $3.22394^{*}$ & 3.45992 & 3.82112 \\
\hline
\end{tabular}

Selection-order criteria: Sample: $5-70$, Number of obs $=66 \quad$ Source: The authors' analysis results

According to the results of testing the optimal lag, the criteria LR, FPE, AIC showed that the model had an optimal lag of 4.

\section{Cointegration test}

Table 4

Johansen test for cointegration

\begin{tabular}{cccccc}
\hline maximum rank & parms & LL & eigenvalue & $\begin{array}{c}\text { Trace } \\
\text { Statistic }\end{array}$ & 5\% critical value \\
\hline 0 & 10 & -108.00404 & & 25.2622 & 15.41 \\
1 & 13 & -97.890287 & 0.26053 & 5.0399 & 3.76 \\
\hline
\end{tabular}

Trend: constant, Sample: $4-70$, Number of obs $=67$, Lags $=3$

Source: The authors' analysis results 
The results of the cointegration test showed that there was no cointegration in the long run in the data series; therefore, the authors used the VAR model with the optimal lag of 4 in the study (Engle and Granger, 1987).

\subsection{Research results and discussion}

Table 5

Results of assessing the impact of exchange rate volatility on the trade balance

\begin{tabular}{|c|c|c|}
\hline \multirow{2}{*}{ Variable } & \multicolumn{2}{|c|}{$\Delta$ tb } \\
\hline & Regression coefficient & Significance level \\
\hline Constant & 303.9913 & 0.609 \\
\hline$\Delta \operatorname{tb}(-1)$ & 0.7005414 & $0.000^{* * *}$ \\
\hline$\Delta \operatorname{tb}(-2)$ & 0.2552627 & $0.089^{*}$ \\
\hline$\Delta$ tb $(-3)$ & -0.5224003 & $0.002^{* * *}$ \\
\hline$\Delta$ tb $(-4)$ & 0.3634498 & $0.010^{* *}$ \\
\hline$\Delta$ vol_reer(-1) & 613225.6 & 0.567 \\
\hline$\Delta$ vol_reer(-2) & -2233810 & $0.067^{*}$ \\
\hline$\Delta$ vol_reer(-3) & 1512791 & 0.178 \\
\hline$\Delta$ vol_reer(-4) & -693200.4 & 0.457 \\
\hline
\end{tabular}

Note: *, ** and $* * *$ indicate significance at the $10 \%, 5 \%$ and $1 \%$ levels, respectively.

Source: The authors' analysis results

After testing the VAR model, the authors performed the autocorrelation test and the stability of the model. The test results showed that there was no autocorrelation between the residuals and the solutions are in the unit circle; therefore, the VAR model with the lag of 4 is stable and suitable. The impulse response function of the past "tb" variable to the current "tb" variable showed that the current trade balance was affected by the volatility of the past trade balance (with the lag from 1 quarter to 4 quarters). The strongest impact level was in the lag from 1 quarter to 2 quarters and decreased gradually in the lag from 3 quarters to 4 quarters. After that, the trade balance gradually recovered and stabilized (Fig. 2).

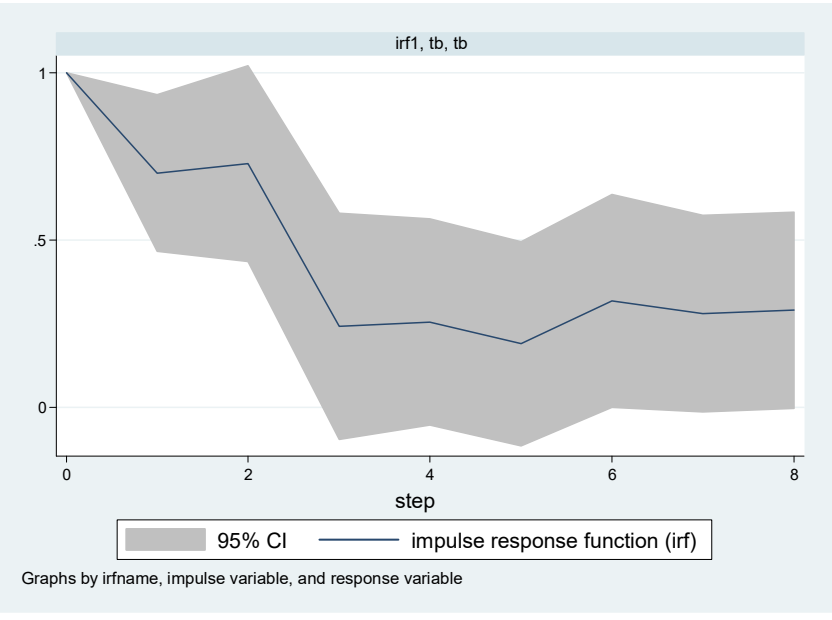

Fig. 2. The impulse response of the past "tb" variable to the current "tb" variable

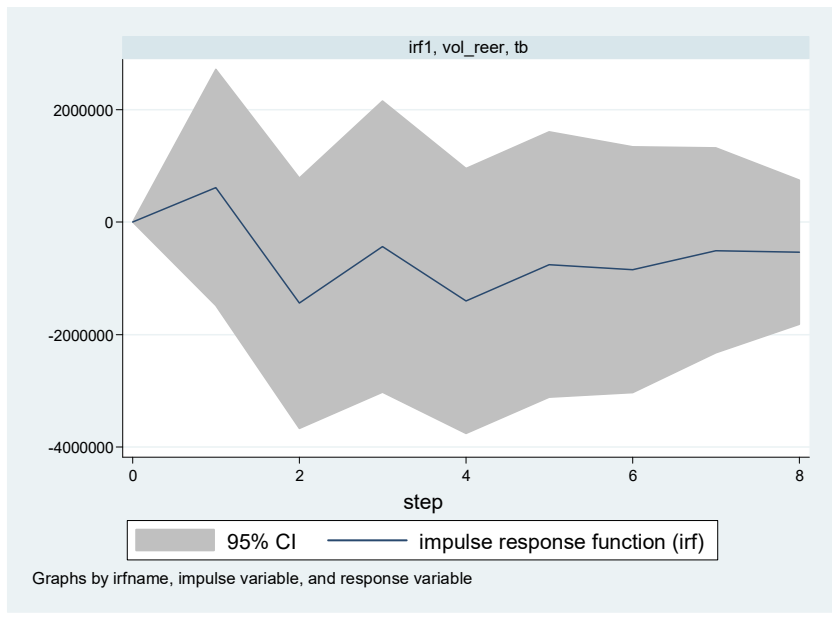

Fig. 3. The impulse response of the variable "vol_reer" to the variable "tb"

The research results also showed that the variable $\Delta$ vol_reer (-2) had a negative impact on the variable $\Delta$ tb at a statistically significant level of $10 \%$. Specifically, the exchange rate volatility with the lag of 2 reduced Vietnam's trade balance. The results are supported by previous studies such as Koray and Lastrapes (1989); Cao-Alvira (2014); Nguyen Thi Van Nga (2018). The study indicated that Vietnam's trade balance had significant responses to real effective exchange rate volatility. Therefore, in addition to other macroeconomic policies, Vietnam needs to pay attention to the adjustment of appropriate exchange rate policies to stabilize the exchange rate and reduce real effective exchange rate volatility to contribute to the improvement of the multilateral trade balance with the partners around the world.

\section{Conclusion}

The study used the vector autoregression (VAR) model to test the impact of real effective exchange rate volatility on trade balance in Vietnam. The result shows that the current trade balance is affected by the volatility of the past trade balance with the lag from 1 quarter to 4 quarters. It also found that the real effective exchange rate volatility have a negative effect on the trade balance at a 2-quarter delay. This result is an evidence of the regime on floating exchange rates under the governmental 
control, which Vietnam pursuing, to be appropriate. In reality, most of the world's currencies are floating, but the government will intervene at a "critical" moment so that the exchange rate does not fully respond to the market, contributing to economic growth as well as achieving inflation control targets. In Vietnam, the foreign exchange market has not yet been able to respond to the complete floating, and the government intervention to keep the exchange rate relatively stable is necessary. Our results support this view. With the lag of 2 quarters, exchange rate volatility reduces the trade balance, and with the lag of 1 quarter, the trade balance has not been able to respond to exchange rate volatility; however, until the 3rd quarter onwards, the exchange rate mechanism promptly changes to stabilize the trade balance. Therefore, Vietnam needs to pay attention to adjusting the exchange rate appropriately to stabilize the exchange rate and reduce the real effective exchange rate volatility to contribute to the improvement of the multilateral trade balance with trading partners. The research results help the policymakers, regulators and researchers to see the impact of exchange rate volatility on the trade balance in Vietnam. The study also has some limitations such as some control variables that may affect Vietnam's trade balance are not mentioned. They will be the next for further studies.

\section{References}

Baharumshah, A. Z. (2001). The effect of exchange rate on bilateral trade balance: new evidence from Malaysia and Thailand. Asian Economic Journal, 15(3), 291-312.

Boyd, D., Caporale, G. M., \& Smith, R. (2001). Real exchange rate effects on the balance of trade: cointegration and the Marshall-Lerner condition. International Journal of Finance \& Economics, 6(3), 187-200.

Cao-Alvira, J. J. (2014). Real exchange rate volatility on the short-and long-run trade dynamics in Colombia. The International Trade Journal, 28(1), 45-64.

Çelik, S., \& Kaya, H. (2010). Real exchange rates and bilateral trade dynamics of Turkey: panel cointegration approach. Applied Economics Letters, 17(8), 791-795.

Dickey, D. A., \& Fuller, W. A. (1979). Distribution of the estimators for autoregressive time series with a unit root. Journal of the American statistical association, 74(366a), 427-431.

Dogru, T., Isik, C., \& Sirakaya-Turk, E. (2019). The balance of trade and exchange rates: Theory and contemporary evidence from tourism. Tourism Management, 74, 12-23.

Do, Thi Man. (2017). Applying the vector autoregression (VAR) model to analyze the impact of exchange rate on Vietnam's trade balance. Journal of Economics and Development, 242(2), 8-18.

Engle, R. F., \& Granger, C. W. (1987). Co-integration and error correction: representation, estimation, and testing. Econometrica: journal of the Econometric Society, 251-276.

Gil-Alana, L. A., Luqui, N., \& Cunado, J. (2008). Trade Balance and Exchange Rate: Unit Roots, Co-integration and Long Memory in the US and the UK. Economic Notes, 37(1), 59-74.

Haddad, A. (2019). Analysis of the bilateral trade between gulf cooperation council countries. Management Science Letters, 9(13), 2357-2368.

Hooper, P., \& Kohlhagen, S. W. (1978). The effect of exchange rate uncertainty on the prices and volume of international trade. Journal of international Economics, 8(4), 483-511.

Koray, F., \& Lastrapes, W. D. (1989). Real exchange rate volatility and US bilateral trade: a VAR approach. The Review of Economics and Statistics, 708-712.

Lin, S., Shi, K., \& Ye, H. (2018). Exchange rate volatility and trade: The role of credit constraints. Review of Economic Dynamics, 30, 203-222.

Musila, J. W. (2002). Exchange rate changes and trade balance adjustments in Malawi. Canadian Journal of Development Studies/Revue canadienne d'études du développement, 23(1), 69-85.

Ngo, T., Tran, T., \& Ngo, A. (2020). Impact of different factors on Vietnam's trade balance. Accounting, 6(4), 605-610.

Nguyen, Thi Van Nga. (2018). Exchange rate volatility affecting Vietnam's trade balance. Journal of Economic Research, 7 , 41-51.

Singh, T. (2004). Testing J-curve hypothesis and analysing the effect of exchange rate volatility on the balance of trade in India. Empirical economics, 29(2), 227-245.

Yol, M. A., \& Baharumshah, A. Z. (2007). Estimating Exchange Rate and Bilateral Trade Balance Relationships: The Experience of Sub-Saharan African Countries. South African Journal of Economics, 75(1), 35-51.



(C) 2020 by the authors; licensee Growing Science, Canada. This is an open access article distributed under the terms and conditions of the Creative Commons Attribution (CC-BY) license (http://creativecommons.org/licenses/by/4.0/). 